\title{
The 10th Biennial Hatter Cardiovascular Institute workshop: cellular protection-evaluating new directions in the setting of myocardial infarction, ischaemic stroke, and cardio-oncology
}

\author{
Sean M. Davidson ${ }^{1} \cdot$ Sapna Arjun $^{1} \cdot$ Maryna V. Basalay $^{1} \cdot$ Robert M. Bell $^{1} \cdot$ Daniel I. Bromage $^{2} \cdot$ Hans Erik Bøtker $^{3}$. \\ Richard D. Carr ${ }^{1,4}$. John Cunningham ${ }^{5}$. Arjun K. Ghosh ${ }^{1}$. Gerd Heusch ${ }^{6} \cdot$ Borja Ibanez $^{7,8,9} \cdot$ Petra Kleinbongard $^{6}$. \\ Sandrine Lecour ${ }^{10} \cdot$ Helen Maddock $^{11} \cdot$ Michel Ovize $^{12} \cdot$ Malcolm Walker $^{1} \cdot$ Marlene Wiart $^{12,13} \cdot$ Derek M. Yellon $^{1}$
}

Received: 3 October 2018 / Accepted: 4 October 2018 / Published online: 11 October 2018

(c) The Author(s) 2018

\begin{abstract}
Due to its poor capacity for regeneration, the heart is particularly sensitive to the loss of contractile cardiomyocytes. The onslaught of damage caused by ischaemia and reperfusion, occurring during an acute myocardial infarction and the subsequent reperfusion therapy, can wipe out upwards of a billion cardiomyocytes. A similar program of cell death can cause the irreversible loss of neurons in ischaemic stroke. Similar pathways of lethal cell injury can contribute to other pathologies such as left ventricular dysfunction and heart failure caused by cancer therapy. Consequently, strategies designed to protect the heart from lethal cell injury have the potential to be applicable across all three pathologies. The investigators meeting at the 10th Hatter Cardiovascular Institute workshop examined the parallels between ST-segment elevation myocardial infarction (STEMI), ischaemic stroke, and other pathologies that cause the loss of cardiomyocytes including cancer therapeutic cardiotoxicity. They examined the prospects for protection by remote ischaemic conditioning (RIC) in each scenario, and evaluated impasses and novel opportunities for cellular protection, with the future landscape for RIC in the clinical setting to be determined by the outcome of the large ERIC-PPCI/CONDI2 study. It was agreed that the way forward must include measures to improve experimental methodologies, such that they better reflect the clinical scenario and to judiciously select combinations of therapies targeting specific pathways of cellular death and injury.
\end{abstract}

Keywords Anthracycline cardiotoxicity $\cdot$ Cardioprotection $\cdot$ Ischaemic stroke $\cdot$ Myocardial ischaemia $\cdot$ Neuroprotection $\cdot$ Reperfusion

Derek M. Yellon

D.Yellon@ucl.ac.uk

1 The Hatter Cardiovascular Institute, Institute of Cardiovascular Science, University College London, 67 Chenies Mews, London WC1E 6HX, UK

2 School of Cardiovascular Medicine and Sciences, King's College London British Heart Foundation Centre of Excellence, James Black Centre, 125 Coldharbour Lane, London SE5 9NU, UK

3 Department of Cardiology, Aarhus University Hospital, Palle Juul-Jensens Boulevard 99, 8200 Aarhus N, Denmark

4 MSD A/S, Copenhagen, Denmark

5 Centre for Nephrology, UCL Medical School, Royal Free Campus, Rowland Hill Street, London NW3 2PF, UK

6 West German Heart and Vascular Center, Institute for Pathophysiology, University of Essen Medical School, Essen, Germany
7 Centro Nacional de Investigaciones Cardiovasculares (CNIC), Madrid, Spain

8 CIBER de Enfermedades CardioVasculares, Madrid, Spain

9 IIS-Fundación Jiménez Díaz University Hospital, Madrid, Spain

10 Cardioprotection Group, Hatter Institute for Cardiovascular Research in Africa, University of Cape Town, Cape Town, South Africa

11 Centre for Sport, Exercise and Life Sciences, Faculty of Health and Life Sciences, Coventry University, Priory Street, Coventry CV1 5FB, UK

12 INSERM U1060, CarMeN Laboratory, Université de Lyon and Service d'explorations Fonctionnelles Cardiovasculaires Groupement Hospitalier Est, 59 Boulevard Pinel, 69500 Bron, France

13 CNRS, Lyon, France 


\section{Introduction}

Unlike some organs that readily regenerate following injury, the adult heart lacks meaningful quantities of endogenous stem cells able to regenerate cardiomyocytes [70] — when a cardiomyocyte is lost, it is gone forever. It is, therefore, imperative to preserve the ones we have. In most cases, the heart endures extraordinarily well, continuing to function for upwards of 70 years or more with exactly the same cardiomyocytes it started with. However, an ST-segment elevation myocardial infarction (STEMI) causes an onslaught of damage that can wipe out over a billion cardiomyocytes [77]. Of patients who reach the hospital and are treated with optimal therapy, $>10 \%$ will die within 1 year, and many of those who survive will go on to develop heart failure as a consequence of the initial infarct [53, 82]. Over the past 25 years, the creation of an emergency care infrastructure enabling rapid myocardial reperfusion has greatly improved clinical outcomes [90]. Unfortunately, in many countries, the reward available from further logistical improvements in the implementation of this intervention appears to have reached its practical limit. For example, in the recent SWEDE HEART study, despite an impressive decrease in the numbers of deaths following STEMI, made after the introduction of emergency coronary care and the implementation of reperfusion therapy, 1-year mortality has remained stubbornly high at $~ 15 \%$ [95].

Like the heart, the adult brain has extremely limited capacity to make new cells, and acute obstruction of a conduit artery causes the irreversible loss of cells-a typical ischaemic stroke causes the loss of $\sim 1$ billion neurons [87]. Stroke causes $9 \%$ of all deaths making it the second leading cause of death and one of the most costly and devastating clinical syndromes in the world [30]. Approximately $20 \%$ of strokes are caused by intracerebral haemorrhage, while the other $\sim 80 \%$ are classified as ischaemic. With the discovery of thrombolysis, reperfusion therapy became an option for the treatment of ischaemic stroke. More recently, the introduction of mechanical thrombectomy has brought about a paradigm shift in the optimal management of ischaemic stroke patients, in particular those with large vessel occlusion who had had poor recanalization rates with thrombolysis [18]. Endovascular recanalization results in rapid restoration of blood flow to the ischaemic cerebrum with the promise of improving neurological salvage and functional outcome. The sequelae of reperfusion for stroke are similar to those seen during primary percutaneous coronary intervention for STEMI [58]. Importantly, in both the brain [35] and myocardium [58], early reperfusion is the only therapy that is proven to limit infarct size in patients. However, a substantial number of stroke patients who receive thrombolysis and/ or thrombectomy in the acute phase never fully recover [35]. This highlights the need to develop new adjunctive neuroprotective treatment strategies alongside reperfusion therapy.

Another of the major killers worldwide is cancer, which affects more than one in three people in their lifetime [74]. Anthracyclines such as doxorubicin are highly effective and commonly used chemotherapeutic agents, but are restricted by dose-limiting cardiotoxicity [74]. Although the incidence of anthracycline-induced cardiomyopathy has declined with contemporary dosing regimens, a significant number of patients develop left ventricular dysfunction and heart failure. The exact proportion of patients affected is difficult to ascertain due primarily to methodological issues, but has been estimated to be in the range of $3-26 \%$ [14]. The cause of myocardial injury is multifarious, but is believed to include oxidative stress, inhibition of topoisomerase II $\beta$, mitochondrial dysfunction, and deficits in cardiomyocyte energy production, which lead to diffuse cardiomyocyte death [14, 37, 38, 74]. Although discussion focussed on anthracyclines, other types of cancer therapy such as HER2 inhibitors can cause similar cardiac injury leading to heart failure [24, 97].

In all three fields mentioned above, and discussed during this workshop, discoveries of protective agents that are effective in experimental studies have failed to translate well to clinical studies in patients. The reasons for this have been extensively discussed in debates that have progressed similarly in each of the research domains. In the field of cardioprotection, recommendations have been published including those deriving from previous Hatter Institute workshops [11, 12, 15, 43, 67]. In neuroprotection, the Stroke Treatment Academic Industry Roundtable (STAIR) guidelines defined similar standards for optimal experimental design [34], which have been improved upon over subsequent years $[65,66]$. Recommendations have also been published for pre-clinical studies of chemotherapy-induced cardiotoxicity and associated assessment of early subclinical myocardial injury biomarkers such as microRNAs $[72,86]$. A common theme in these guidelines is the apparent disconnect between overly simplistic experimental models using young, healthy animals, and the complex reality of the clinical scenario $[11,12,15,34$, $43,47,49,55,67,84]$.

In view of the above, a key question discussed at the workshop was whether there is any commonality between the mechanisms of cell death that occur in these three pathologies and, if so, whether this knowledge can inform the development of improved cytoprotective modalities that are able to improve clinical outcome in patients. 


\section{The same but different}

Superficially, at least, there are a number of obvious commonalities between STEMI and ischaemic stroke, which raise the interesting possibility that protective modalities successful in one scenario may also be effective in the other (Table 1). On the other hand, there are clearly also specific differences that may impede the blanket application of therapies across these scenarios (Table 1). While cardiomyocyte death is also integral to cardiotoxicity after cancer chemotherapy, its similarity to the cell death that occurs during ischaemia-reperfusion is more controversial and will be discussed later.

Both ischaemic stroke and STEMI are usually caused by obstruction of a main conduit artery by a blood clot. In the heart, the clot typically forms in the region, where an atherosclerotic plaque has ruptured [99]. The resulting hypoperfusion in the ischaemic "area at risk" will lead to cell death if recanalization does not occur promptly. Some of the area at risk will be salvaged by reperfusion, and its effectiveness can be further improved by interventions such as ischaemic preor post-conditioning [31, 41, 54]. In the brain, thromboembolic stroke is more common, but up to $40 \%$ of all ischaemic strokes are of unknown aetiology [30]. In ischaemic stroke, there may be a zone of non-functioning but viable tissue that has the potential to recover its function if blood flow can be restored, for example, by therapeutic intervention. This region is referred to as the ischaemic "penumbra" [5].

At a cellular level, the response to ischaemia is broadly similar in the heart and brain [57]. Since neurons and cardiomyocytes rely on high rates of oxidative phosphorylation for the production of ATP, in the absence of oxygen, ATP is rapidly depleted. While cells can survive on ATP produced by glycolysis for a short time, eventually, this decreases to levels that are insufficient to maintain essential ion homeostasis, and $\mathrm{Ca}^{2+}$ begins to flood in and overload the cells. Reperfusion restores the essential flow of oxygen and nutrients to starved cells [21]. In both heart and brain, the mitochondria are the source of their own demise, as rapid re-activation of the electron transport chain results in a burst of superoxide production, which conspires with calcium to increase opening of the mitochondrial permeability transition pores (MPTP) [8, 28, 71, 89]. Above a critical threshold, damage is irreversible and catastrophic injury results in cell death, primarily by necrosis/oncosis. Other types of cell death such as necroptosis are also involved [69, 93]. Apoptosis is important in the brain, but its role in the reperfused heart is more controversial $[17,59,62,68]$. Although the mechanisms of cellular injury caused by ischaemia-reperfusion are very similar in the heart and brain, the brain is uniquely sensitive to damage caused by glutamate released from depolarized cells which causes glutamate excitotoxicity $[45,83]$.
However, infarction causes more than just the death of cardiomyocytes or neurons. The vasculature is essential not just for delivery of oxygenated blood, but for insulating the parenchyma from blood constituents and excessive liquid. This is particularly important in the brain, where energy depletion and blood-brain-barrier dysfunction can result in malignant oedema, a major cause of death following stroke [9]. Disruption of the neurovascular unit (which comprises endothelial cells, pericytes, vascular smooth muscle cells, astrocytes, microglia, and neurons) may also lead to further neuronal death. The vessels of the heart have an analogous, non-fenestrated endothelial cell layer, which is in some sense a "blood-heart barrier". Damage to the cardiac endothelium can also result in oedema [48].

The debate about the significance of the differences between brain and heart, and their impacts on protection, led to the question of what is the most important experimental outcome. In experimental myocardial infarction studies, the gold standard and primary measure of outcome is infarct size (as a percentage of area at risk) [15], which predicts progression to heart failure in patients [94]. However, in the brain, infarct location is far more important than infarct size per se in determining functional outcome. For this reason, both neuroscore and infarct size should be considered in neuroprotection studies. The use of multiparametric MRI to assess per-occlusion and follow-up brain damage has the potential to improve translation by providing the same imaging endpoints in both the pre-clinical and clinical settings [19]. One of the greatest fears for the neurologist ministering to a patient with ischaemic stroke is haemorrhagic transformation $[9,30]$, whereas in the heart, haemorrhage is not a prime concern.

In both brain and heart, the degree of injury is highly dependent on the duration, extent and severity of ischaemia $[51,76]$. The sole therapy available for each is reperfusion. The kinetics of reperfusion may be very different in patients treated with thrombolysis vs PCI or mechanical thrombectomy. Most experimental models, however, study reperfusion as an acute event. Rodent models of thromboembolic stroke amenable to thrombolysis do exist, but require more animals per group due to inherently greater experimental variability (see, for example, [102]). Reperfusion injury has been well studied in the heart, and is also thought to occur in the brain $[4,7,68,79,83]$. As such, targeting reperfusion injury should be considered an effective means of developing additional adjunctive therapies in patients with acute ischaemic stroke $[62,88]$. Another key determinant of ischaemia-reperfusion injury in both heart and brain is the extent of collateralization. In the brain, some functional redundancy of blood supply is naturally provided by the circle of Willis (Fig. 1) - although the precise anatomy of these vessels can be quite variable between patients. Furthermore, the functionality of secondary collateral pathways such as 


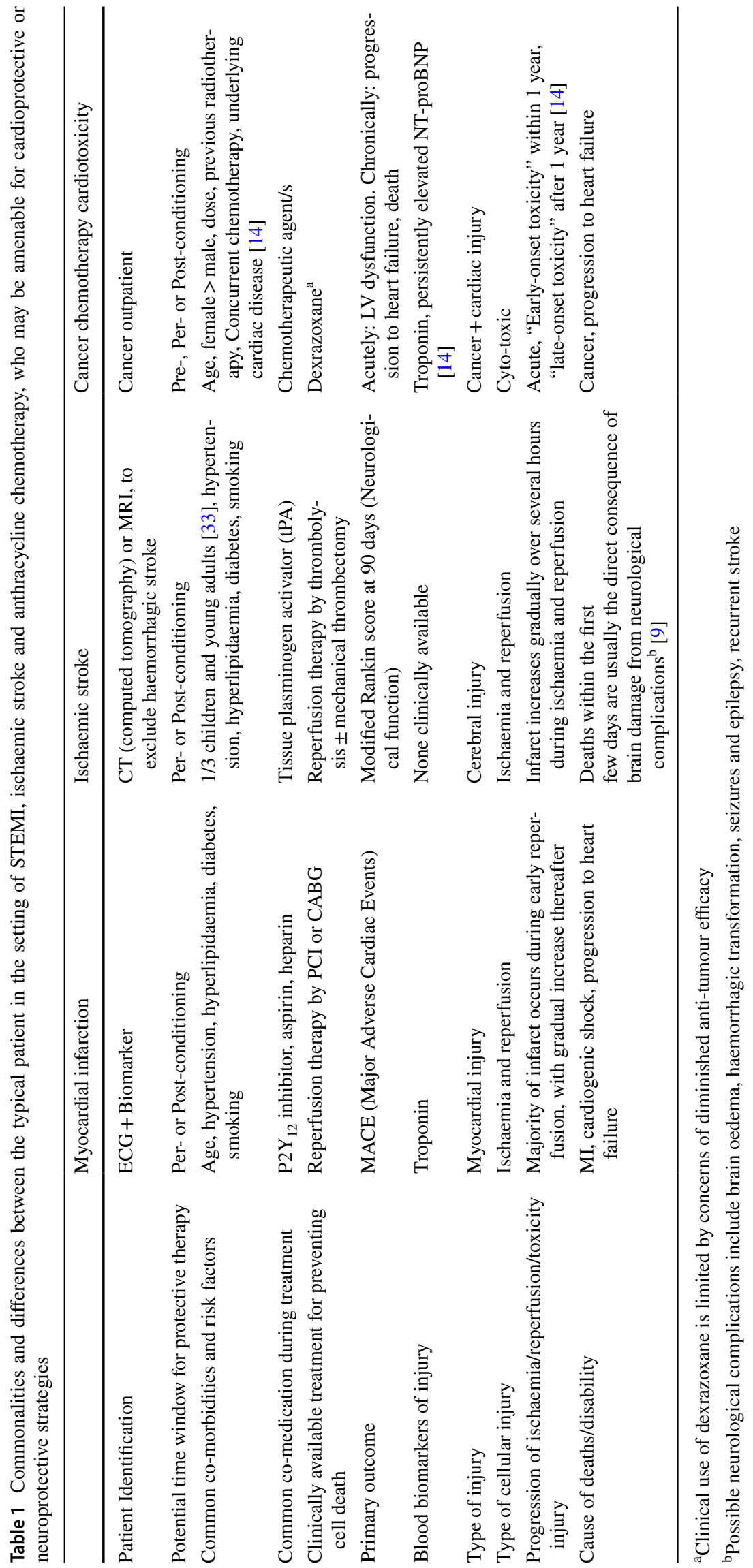




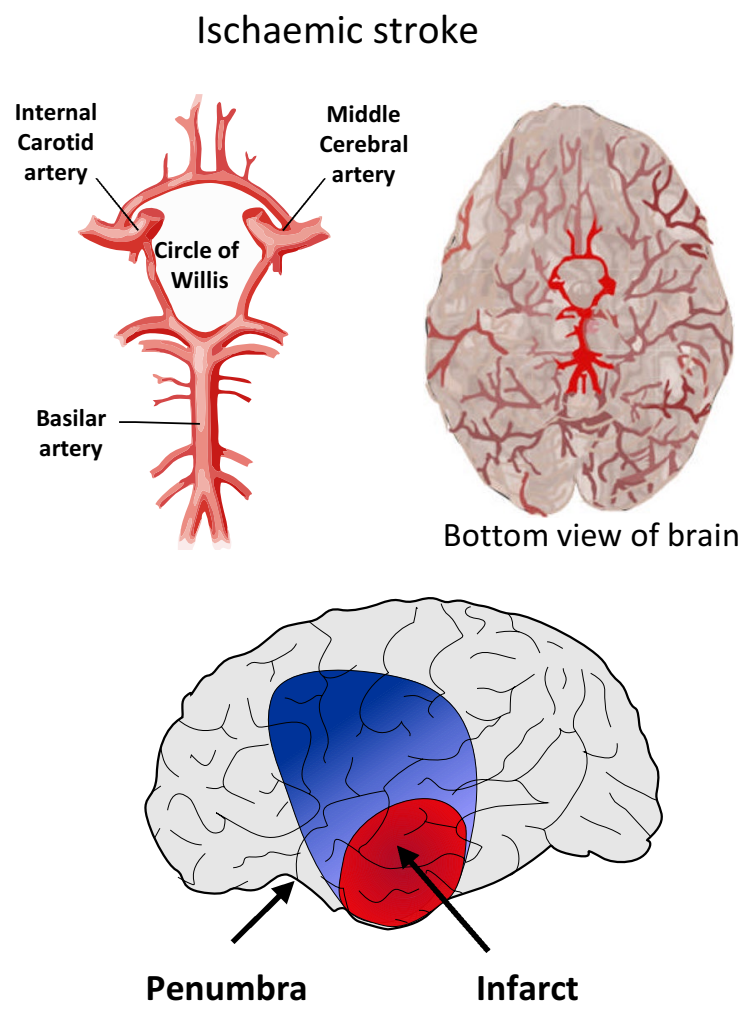

Fig. 1 In the brain, middle cerebral artery occlusion results in a gradient of reduction in cerebral blood flow from the ischaemic core (red) through the penumbra and oligaemia (blue) to normally perfused cortex (grey). No reflow may also occur from 5 to $10 \mathrm{~min}$. In

leptomeningeal anastomoses is believed to be a main determinant of stroke outcome [39].

Even after successful recanalization of the occluded vessel, reperfusion at the level of the tissue may be limited-a situation called "no reflow". No reflow occurs in both the heart and the brain but with very different kinetics and a partially distinct mechanism $[48,52,64]$. No reflow can occur within 5-10 min of ischaemia in the brain [3], and may, therefore, contribute to neuronal death, whereas in the heart it only occurs after $30+\mathrm{min}$ and its contribution to cell death is less clear [64]. The fact that the brain is confined within a rigid skull may contribute to the differences in the manifestation of no reflow [64]. In the brain, perfusion deficits occur in a gradient from the infarct through to an oligaemic region of mildly reduced blood flow, via an ischaemic penumbra of potentially salvageable tissue.

With regard to the above discussion, it was unanimously agreed that experimentally; in both heart and brain, it is crucial to accurately determine the volume of tissue that is ischaemic and, therefore, at risk of infarction. While in the heart, this can be readily achieved by Evans blue staining ex vivo, or the use of microspheres, in the brain this is not a trivial matter due to its extensive collateralization. The

\section{Myocardial infarction}
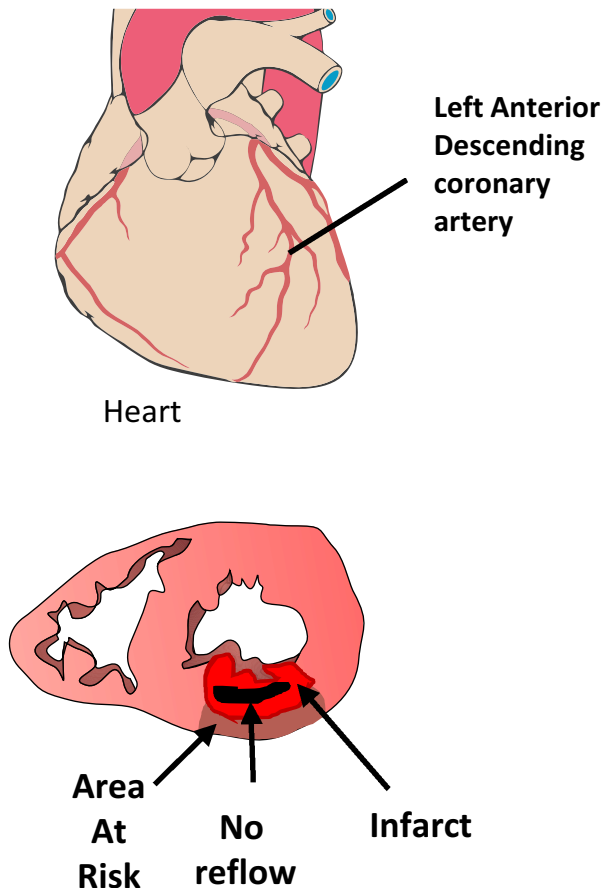

the heart, occlusion of the LAD followed by reperfusion results in an ischaemia area risk in which a transmural infarct slowly develops, followed by the appearance of a zone of no reflow within the infarct

clinical method of estimating the ischaemic penumbra by measuring the per-occlusion perfusion/diffusion mismatch by MRI can also be applied in animal models of transient stroke (Fig. 2) [29]. Thus, MRI has the potential to improve the overall methodology of pre-clinical neuroprotection studies, with the advantage that it can also be used to provide a measure of infarct size that matches well with tetrazolium chloride staining [20].

The use of rodent models in cardioprotection and neuroprotection has limitations. There are clearly major differences between lissencephalic brains of small mammals and gyrencephalic brains of larger species, which lead to the recommendation to confirm results in rabbits or non-human primates [66]. Similar reasoning is frequently used to support the need for cardioprotection studies in pigs [56] prior to clinical studies, although one might question whether healthy pig hearts, with their low native collateralization, are generally the ideal model of patients with coronary artery disease (CAD), who may or may not be highly collateralized.

One factor specific to MI, which may have contributed to the poor translation of cardioprotection between animal models of ischaemia-reperfusion injury and patients, is the clinical use of $\mathrm{P}_{2} \mathrm{Y}_{12}$ platelet inhibitors, which exhibit 


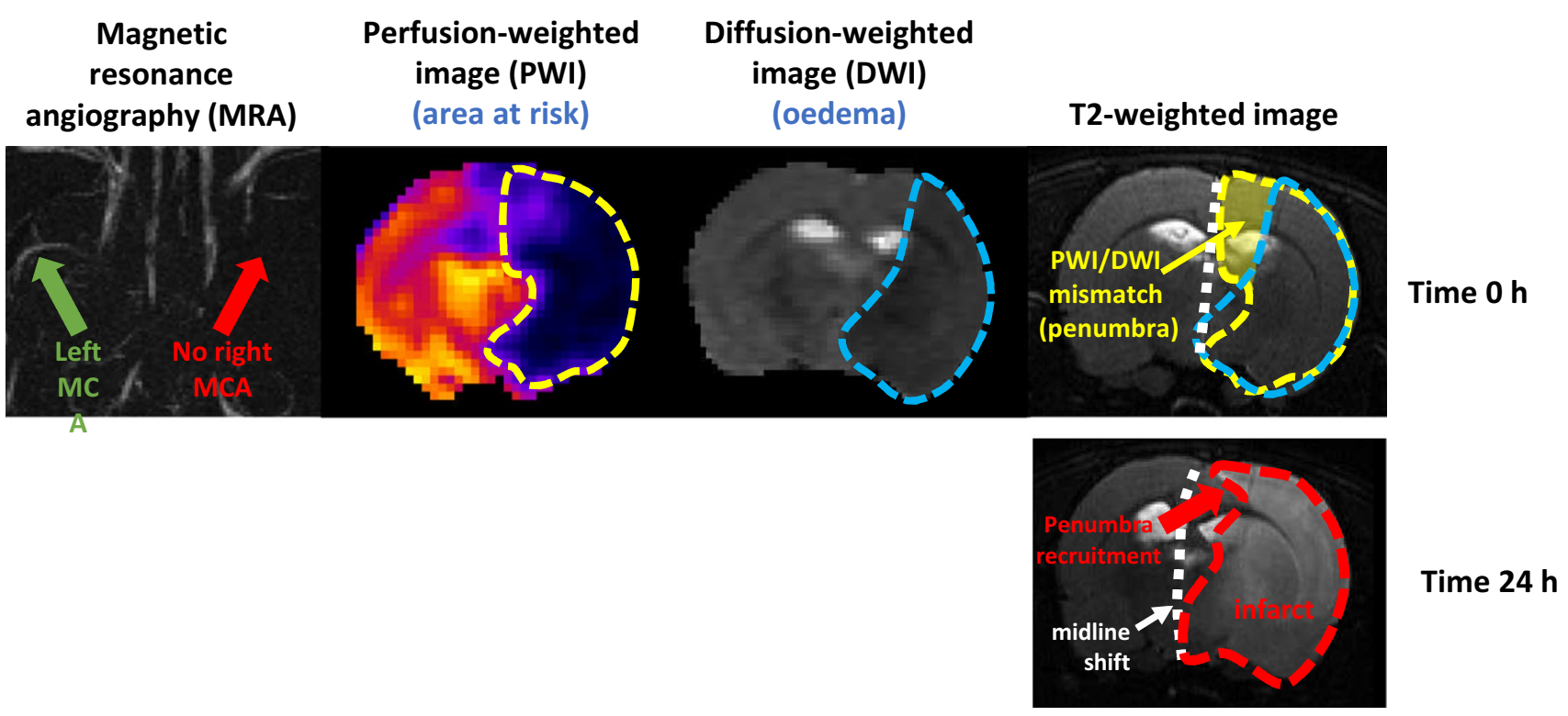

Fig. 2 MRI images of a rat subject to middle cerebral artery (MCA) occlusion and reperfusion, illustrating recruitment of the ischaemic penumbra in the infarct. The top panels confirm the complete occlusion of the MCA and show the perfusion-weighted and diffu-

coagulation-independent cardioprotection in their own right $[12,23]$. Although nearly all STEMI patients receive such medication, platelet inhibitors are not used at the time of recanalization in stroke for fear of causing haemorrhagic conversion. Thus, this potential confounding factor is only relevant to STEMI and not to ischaemic stroke.

At another level, several parallels can be drawn between the mechanism of cardiac injury caused by STEMI and anthracycline cardiotoxicity, including the role of oxidative stress, mitochondrial damage, and cardiomyocyte death [37, $38,74]$. It was noted that current clinical trials aim to treat heart failure after it has been detected, but not to prevent the cause-which is cardiomyocyte death. New experimental studies are needed of agents that are better able to protect the cardiomyocytes from anthracycline toxicity, with the added condition that they must absolutely not reduce the efficacy of the cancer treatment [74].

\section{Cyto-protection-the present situation}

A number of issues were discussed at this workshop that are relevant to each of the three pathological scenarios described above. It was agreed that one of the most promising forms of cyto-protection is the phenomenon of remote ischaemic conditioning (RIC) [40, 46, 50]. RIC is a highly robust method of reducing myocardial infarct size in animal models [16] as well as in proof of concept clinical studies [51]. One outstanding issue that was discussed at the workshop relates to the RIC protocol, which remains to be optimized in humans. sion-weighted images, which when combined reveal the ischaemic penumbra. In the lower panel, after $24 \mathrm{~h}$ part of the penumbra has been recruited into the area of infarct, and brain swelling has caused a quantifiable shift of the midline

Despite efforts made in this regard in animal models [16, $60]$, clinical trials typically use a protocol of 3 or 4 cycles of $5 \mathrm{~min}$ upper limb ischaemia (maximum $200 \mathrm{mmHg}$ ) followed by 5 min reperfusion, which was effective in phase 1 trials [51]. Yet, no phase II trials have been performed.

RIC has repeatedly been shown to reduce the release of cell-death biomarkers such as troponin or creatine kinase in pilot studies of STEMI [51]. Interestingly, there are also indications of improvements in long-term clinical outcome with significant reductions in major adverse cardiac and cerebrovascular events (MACCE) [91] and mortality [36]. It was felt that STEMI remained the most important target for cardioprotection from RIC or pharmacological therapy. It was debated whether other settings such as CABG, which has had two neutral clinical outcome studies [42,75], should still be considered amenable for cardioprotection $[63,96]$.

Results are eagerly awaited from the ERIC-PPCI/ CONDI-2 study investigating the effect of RIC on clinical outcomes in patients presenting with an STEMI undergoing primary percutaneous coronary intervention [44]. All participants at the workshop agreed that the outcome of this pivotal study will determine the direction that cardiovascular research will take for the next decade. However, irrespective of the results of this study, what is true for the heart might not be true for the brain.

Evidence was shown that ischaemic preconditioning (IPC) may be able to protect cardiac cells from anthracycline toxicity, while not increasing the survival of cancer cells [73]. A clinical study is currently being undertaken to 
assess the efficacy of RIC in patients receiving doxorubicin for cancer therapy [22].

Derek Yellon presented data obtained using a new experimental rat model that could potentially be used to evaluate cardioprotection on a background of agents commonly administered to STEMI patients. These preliminary studies were designed to ascertain if it is possible to obtain an animal model more representative of patients and included the use of an anticoagulant, an analgesic and antiplatelet agent. The participants agreed that this represented a promising first step to overcoming some of the translational hurdles that have impaired translation.

The prevalence of obesity and diabetes is steadily increasing and is predicted to cause the incidence of myocardial infarction and strokes to soar in the next two decades. Diabetes and other co-morbidities worsen the outcome from both STEMI and ischaemic stroke, and also impair cardioprotective and neuroprotective strategies in animal models $[32,67,80]$. Given the above, Derek Yellon proposed that a multi-targeted strategy would be required to protect the heart or brain from IR injury as a way forward [25, 85].

However, despite the overall negative impact of diabetes on the cardiovascular system, it has perhaps been indirectly responsible for shining a glimmer of light onto the field of cardioprotection. There was an interesting discussion about the cardioprotective benefit that has now been seen in three, separate, large clinical trials of antidiabetic therapies, namely, the SGLT2 inhibitors $[2,101]$. These results from recent large clinical studies show conclusively that cardioprotection is a viable option. What is now required is to ascertain the mechanism by which these agents elicit their protection [13].

\section{The way forward}

A succinct set of ten guidelines were put forward at the previous Hatter meeting [12]. Many of these proposals have been incorporated into subsequent statements and recommendations. In particular, it was felt that, given the multiple redundancies in cell death pathways, targeting of a single pathway may be unable to afford sufficient protection for clinical benefit. As such, it is important to investigate all the forms of cell death to achieve maximum protection.

To increase the potency of protection and inhibit alternative death pathways, a multi-target therapeutic approach may be necessary to achieve a clinically meaningful benefit [25]. Additive cardioprotection has been seen, e.g., with the caspase 1 inhibitor VX-765 administered at reperfusion in $\mathrm{P}_{2} \mathrm{Y}_{12}$ receptor antagonist-treated rats [6]. Combination therapy may also have the potential to protect against acute ischaemic stroke, but this important concept remains unproven in this setting $[81,100]$. To design a rational, multi-targeted approach, it is important to know the mechanisms and perform accurate dose-response experiments. One promising avenue of research is exosomes. These are nanoparticles that have been shown to be cardioprotective in animal models, which may be able to target multiple pathways via their protein and miRNA cargo [26, $27,92,98]$. However, many questions remain, including the real identity of their cellular target in the heart, and optimal methods for their purification and delivery [27].

All participants recognized that a better methodology will be required in order to close the translational "gap". Ultimately, two types of animal models are useful: one which is simplistic, conceptual and reductionist, which can inform about mechanisms and a second type of model that is complex, real-world, clinical, translational, and pragmatic, which can be used as a test bed towards clinical translation.

In line with the previous recommendations, a system is urgently needed to enable the conduct of multi-centre animal trials, much like the CAESAR network previously established in USA [61], or the MULTIPART network for neuroprotection [1]. Interestingly, such a multi-centre, blinded, randomized, controlled experimental infarct study was previously used successfully in the year 2000 to demonstrate that an adenosine A1 agonist at reperfusion was cardioprotective when administered prior to coronary occlusion in rabbits, but not when administered immediately prior to reperfusion [10]. All future studies should follow as closely as possible the appropriate guidelines $[12,15,34,65-67,78]$ on effective translational research.

Acknowledgements NIHR Biomedical Research Council (SD) and the British Heart Foundation PG/18/44/33790, PG/16/85/32471 (SD, DY). German Research Foundation SFB 1116 B08 (GH,PK). This work has been supported by the OPeRa program (ANR-10-IBHU-0004 OPeRa) and completed within the framework of the RHU MARVELOUS (ANR-16-RHUS-0009) (MO).

\section{Compliance with ethical standards}

Conflict of interest Dr Richard Carr is an employee of MSD A/S, Copenhagen V, Denmark. There are no other conflicts of interest to declare.

Open Access This article is distributed under the terms of the Creative Commons Attribution 4.0 International License (http://creativeco mmons.org/licenses/by/4.0/), which permits unrestricted use, distribution, and reproduction in any medium, provided you give appropriate credit to the original author(s) and the source, provide a link to the Creative Commons license, and indicate if changes were made.

\section{References}

1. http://www.den.ed.ac.uk/multipart/default.htm

2. https://www.astrazeneca.com/content/astraz/media-centre/press -releases/2018/farxiga-achieved-a-positive-result-in-the-phase 
-iii-declare-timi-58-trial-a-large-cardiovascular-outcomes-trial -in-17000-patients-with-type-2-diabetes-24092018.html

3. Ames A 3rd, Wright RL, Kowada M, Thurston JM, Majno G (1968) Cerebral ischemia. II. The no-reflow phenomenon. Am J Pathol 52:437-453

4. Aronowski J, Strong R, Grotta JC (1997) Reperfusion injury: demonstration of brain damage produced by reperfusion after transient focal ischemia in rats. J Cereb Blood Flow Metab 17:1048-1056. https://doi.org/10.1097/00004647-19971 0000-00006

5. Astrup J (1982) Energy-requiring cell functions in the ischemic brain. Their critical supply and possible inhibition in protective therapy. J Neurosurg 56:482-497. https://doi.org/10.3171/ jns.1982.56.4.0482

6. Audia JP, Yang X-M, Crockett ES, Housley N, Ul Haq E, O’Donnell K, Cohen MV, Downey JM, Alvarez DF (2018) Caspase-1 inhibition by VX-765 administered at reperfusion in P2Y12 receptor antagonist-treated rats provides long-term reduction in myocardial infarct size and preservation of ventricular function. Basic Res Cardiol 113:32. https://doi.org/10.1007/ s00395-018-0692-z

7. Bai J, Lyden PD (2015) Revisiting cerebral postischemic reperfusion injury: new insights in understanding reperfusion failure, hemorrhage, and edema. Int J Stroke 10:143-152. https://doi. org/10.1111/ijs.12434

8. Baines CP, Kaiser RA, Purcell NH, Blair NS, Osinska H, Hambleton MA, Brunskill EW, Sayen MR, Gottlieb RA, Dorn GW, Robbins J, Molkentin JD (2005) Loss of cyclophilin D reveals a critical role for mitochondrial permeability transition in cell death. Nature 434:658-662. https://doi.org/10.1038/nature03434

9. Balami JS, Chen RL, Grunwald IQ, Buchan AM (2011) Neurological complications of acute ischaemic stroke. Lancet Neurol. 10:357-371. https://doi.org/10.1016/S1474-4422(10)70313-6

10. Baxter GF, Hale SL, Miki T, Kloner RA, Cohen MV, Downey JM, Yellon DM (2000) Adenosine A1 agonist at reperfusion trial (AART): results of a three-center, blinded, randomized, controlled experimental infarct study. Cardiovasc Drugs Ther 14:607-614

11. Bell R, Beeuwkes R, Bøtker HE, Davidson S, Downey J, Garcia-Dorado D, Hausenloy DJ, Heusch G, Ibanez B, Kitakaze M, Lecour S, Mentzer R, Miura T, Opie L, Ovize M, Ruiz-Meana M, Schulz R, Shannon R, Walker M, Vinten-Johansen J, Yellon D (2012) Trials, tribulations and speculation! Report from the 7th Biennial Hatter Cardiovascular Institute Workshop. Basic Res Cardiol 107:300. https://doi.org/10.1007/s00395-012-0300-6

12. Bell RM, Botker HE, Carr RD, Davidson SM, Downey JM, Dutka DP, Heusch G, Ibanez B, Macallister R, Stoppe C, Ovize M, Redington A, Walker JM, Yellon DM (2016) 9th Hatter Biannual Meeting: position document on ischaemia/reperfusion injury, conditioning and the ten commandments of cardioprotection. Basic Res Cardiol 111:41. https://doi.org/10.1007/s0039 5-016-0558-1

13. Bell RM, Yellon DM (2018) SGLT2 inhibitors: hypotheses on the mechanism of cardiovascular protection. Lancet Diabetes Endocrinol 6:435-437. https://doi.org/10.1016/S2213-8587(17)30314 $-5$

14. Bonita R, Pradhan R (2013) Cardiovascular toxicities of cancer chemotherapy. Semin Oncol 40:156-167. https://doi. org/10.1053/j.seminoncol.2013.01.004

15. Botker HE, Hausenloy D, Andreadou I, Antonucci S, Boengler K, Davidson SM, Deshwal S, Devaux Y, Di Lisa F, Di Sante M, Efentakis P, Femmino S, Garcia-Dorado D, Giricz Z, Ibanez B, Iliodromitis E, Kaludercic N, Kleinbongard P, Neuhauser M, Ovize M, Pagliaro P, Rahbek-Schmidt M, Ruiz-Meana M, Schluter KD, Schulz R, Skyschally A, Wilder C, Yellon DM, Ferdinandy P, Heusch G (2018) Practical guidelines for rigor and reproducibility in preclinical and clinical studies on cardioprotection. Basic Res Cardiol 113:39. https://doi.org/10.1007/s0039 5-018-0696-8

16. Bromage DI, Pickard JM, Rossello X, Ziff OJ, Burke N, Yellon DM, Davidson SM (2017) Remote ischaemic conditioning reduces infarct size in animal in vivo models of ischaemia-reperfusion injury: a systematic review and meta-analysis. Cardiovasc Res 113:288-297. https://doi.org/10.1093/cvr/cvw219

17. Cabrera-Fuentes HA, Aragones J, Bernhagen J, Boening A, Boisvert WA, Botker HE, Bulluck H, Cook S, Di Lisa F, Engel FB, Engelmann B, Ferrazzi F, Ferdinandy P, Fong A, Fleming I, Gnaiger E, Hernandez-Resendiz S, Kalkhoran SB, Kim MH, Lecour S, Liehn EA, Marber MS, Mayr M, Miura T, Ong SB, Peter K, Sedding D, Singh MK, Suleiman MS, Schnittler HJ, Schulz R, Shim W, Tello D, Vogel CW, Walker M, Li QO, Yellon DM, Hausenloy DJ, Preissner KT (2016) From basic mechanisms to clinical applications in heart protection, new players in cardiovascular diseases and cardiac theranostics: meeting report from the third international symposium on "New frontiers in cardiovascular research". Basic Res Cardiol 111:69. https://doi. org/10.1007/s00395-016-0586-x

18. Carvalho A, Cunha A, Rodrigues M, Figueiredo S, Paredes L, Gregorio T, Morais H, Pinheiro J, Cruz VT, Roriz JM, Pinho J, Ferreira C, Torre E, Nunes J, Castro S, Ribeiro M, Veloso M, Barros P (2017) Mechanical thrombectomy in acute ischemic stroke: initial single-center experience and comparison with randomized controlled trials. J Stroke Cerebrovasc Dis 26:589-594. https://doi.org/10.1016/j.jstrokecerebrovasdis.2016.11.116

19. Chauveau F, Cho TH, Riou A, Langlois JB, Berthezene Y, Nighoghossian N, Wiart M (2012) Does acute behavioral testing reflect successful ischemia in rats with transient middle cerebral artery occlusion? Int J Stroke 7:465-472. https://doi.org/10.111 1/j.1747-4949.2011.00710.x

20. Chen F, Suzuki Y, Nagai N, Jin L, Yu J, Wang H, Marchal G, Ni Y (2007) Rodent stroke induced by photochemical occlusion of proximal middle cerebral artery: evolution monitored with MR imaging and histopathology. Eur J Radiol 63:68-75. https://doi. org/10.1016/j.ejrad.2007.01.005

21. Chouchani ET, Pell VR, Gaude E, Aksentijević D, Sundier SY, Robb EL, Logan A, Nadtochiy SM, Ord EN, Smith AC, Eyassu F, Shirley R, Hu CH, Dare AJ, James AM, Rogatti S, Hartley RC, Eaton S, Costa AS, Brookes PS, Davidson SM, Duchen MR, Saeb-Parsy K, Shattock MJ, Robinson AJ, Work LM, Frezza C, Krieg T, Murphy MP (2014) Ischaemic accumulation of succinate controls reperfusion injury through mitochondrial ROS. Nature 515:431-435. https://doi.org/10.1038/nature13909

22. Chung R, Maulik A, Hamarneh A, Hochhauser D, Hausenloy DJ, Walker JM, Yellon DM (2016) Effect of remote ischaemic conditioning in oncology patients undergoing chemotherapy: rationale and design of the ERIC-ONC study-a single-center, blinded, randomized controlled trial. Clin Cardiol 39:72-82. https://doi.org/10.1002/clc.22507

23. Cohen MV, Downey JM (2017) The impact of irreproducibility and competing protection from $\mathrm{P} 2 \mathrm{Y} 12$ antagonists on the discovery of cardioprotective interventions. Basic Res Cardiol 112:64. https://doi.org/10.1007/s00395-017-0653-y

24. Crone SA, Zhao YY, Fan L, Gu Y, Minamisawa S, Liu Y, Peterson KL, Chen J, Kahn R, Condorelli G, Ross J Jr, Chien KR, Lee KF (2002) ErbB2 is essential in the prevention of dilated cardiomyopathy. Nat Med 8:459-465. https://doi.org/10.1038/ nm0502-459

25. Davidson SM, Ferdinandy P, Andreadou I, Bøtker HE, Heusch G, Ibáñez B, Ovize M, Schulz R, Yellon DM, Hausenloy DJ, GarciaDorado D (2018) Multi-target strategies to reduce myocardial ischemia/reperfusion injury. J Am Coll, Cardiol (In press) 
26. Davidson SM, Takov K, Yellon DM (2017) Exosomes and cardiovascular protection. Cardiovasc Drugs Ther 31:77-86. https ://doi.org/10.1007/s10557-016-6698-6

27. Davidson SM, Yellon DM (2018) Exosomes and cardioprotection-a critical analysis. Mol Aspects Med 60:104-114. https:// doi.org/10.1016/j.mam.2017.11.004

28. Davidson SM, Yellon DM, Murphy MP, Duchen (2012) Slow calcium waves and redox changes precede mitochondrial permeability transition pore opening in the intact heart during hypoxia and reoxygenation. Cardiovasc Res 93:445-453. https://doi. org/10.1093/cvr/cvr349

29. Donnan GA, Davis SM (2002) Neuroimaging, the ischaemic penumbra, and selection of patients for acute stroke therapy. Lancet Neurol 1:417-425

30. Donnan GA, Fisher M, Macleod M, Davis SM (2008) Stroke. Lancet 371:1612-1623. https://doi.org/10.1016/S0140 -6736(08)60694-7

31. Eitel I, Desch S, de Waha S, Fuernau G, Gutberlet M, Schuler G, Thiele H (2011) Long-term prognostic value of myocardial salvage assessed by cardiovascular magnetic resonance in acute reperfused myocardial infarction. Heart 97:2038-2045. https:// doi.org/10.1136/heartjnl-2011-300098

32. Fadini GP, Cosentino F (2018) Diabetes and ischaemic stroke: a deadly association. Eur Heart J 39:2387-2389. https://doi. org/10.1093/eurheartj/ehy033

33. Feigin VL, Forouzanfar MH, Krishnamurthi R, Mensah GA, Connor M, Bennett DA, Moran AE, Sacco RL, Anderson L, Truelsen T, O'Donnell M, Venketasubramanian N, Barker-Collo S, Lawes CM, Wang W, Shinohara Y, Witt E, Ezzati M, Naghavi M, Murray C, Global Burden of Diseases I, Risk Factors S, the GBDSEG (2014) Global and regional burden of stroke during 1990-2010: findings from the Global Burden of Disease Study 2010. Lancet 383:245-254

34. Fisher M, Feuerstein G, Howells DW, Hurn PD, Kent TA, Savitz SI, Lo EH, Group S (2009) Update of the stroke therapy academic industry roundtable preclinical recommendations. Stroke 40:2244-2250. https://doi.org/10.1161/strokeaha.108.541128

35. Furie KL, Jayaraman MV (2018) 2018 Guidelines for the early management of patients with acute ischemic stroke. Stroke 49:509-510. https://doi.org/10.1161/STROKEAHA.118.020176

36. Gaspar A, Lourenco AP, Pereira MA, Azevedo P, Roncon-Albuquerque R Jr, Marques J, Leite-Moreira AF (2018) Randomized controlled trial of remote ischaemic conditioning in ST-elevation myocardial infarction as adjuvant to primary angioplasty (RICSTEMI). Basic Res Cardiol 113:14. https://doi.org/10.1007/ s00395-018-0672-3

37. Gharanei M, Hussain A, Janneh O, Maddock H (2013) Attenuation of doxorubicin-induced cardiotoxicity by mdivi-1: a mitochondrial division/mitophagy inhibitor. PLoS One 8:e77713. https://doi.org/10.1371/journal.pone.0077713

38. Gharanei M, Hussain A, Janneh O, Maddock HL (2013) Doxorubicin induced myocardial injury is exacerbated following ischaemic stress via opening of the mitochondrial permeability transition pore. Toxicol Appl Pharmacol 268:149-156. https:// doi.org/10.1016/j.taap.2012.12.003

39. Ginsberg MD (2016) Expanding the concept of neuroprotection for acute ischemic stroke: the pivotal roles of reperfusion and the collateral circulation. Prog Neurobiol 145-146:46-77. https ://doi.org/10.1016/j.pneurobio.2016.09.002

40. Hausenloy DJ, Barrabes JA, Botker HE, Davidson SM, Di Lisa F, Downey J, Engstrom T, Ferdinandy P, Carbrera-Fuentes HA, Heusch G, Ibanez B, Iliodromitis EK, Inserte J, Jennings R, Kalia N, Kharbanda R, Lecour S, Marber M, Miura T, Ovize M, PerezPinzon MA, Piper HM, Przyklenk K, Schmidt MR, Redington A, Ruiz-Meana M, Vilahur G, Vinten-Johansen J, Yellon DM, Garcia-Dorado D (2016) Ischaemic conditioning and targeting reperfusion injury: a 30 year voyage of discovery. Basic Res Cardiol 111:70. https://doi.org/10.1007/s00395-016-0588-8

41. Hausenloy DJ, Botker HE, Engstrom T, Erlinge D, Heusch G, Ibanez B, Kloner RA, Ovize M, Yellon DM, Garcia-Dorado D (2017) Targeting reperfusion injury in patients with ST-segment elevation myocardial infarction: trials and tribulations. Eur Heart J 38:935-941. https://doi.org/10.1093/eurheartj/ehw145

42. Hausenloy DJ, Candilio L, Evans R, Ariti C, Jenkins DP, Kolvekar S, Knight R, Kunst G, Laing C, Nicholas J, Pepper J, Robertson S, Xenou M, Clayton T, Yellon DM, Investigators ET (2015) Remote ischemic preconditioning and outcomes of cardiac surgery. N Engl J Med 373:1408-1417. https://doi. org/10.1056/NEJMoa1413534

43. Hausenloy DJ, Garcia-Dorado D, Botker HE, Davidson SM, Downey J, Engel FB, Jennings R, Lecour S, Leor J, Madonna R, Ovize M, Perrino C, Prunier F, Schulz R, Sluijter JPG, Van Laake LW, Vinten-Johansen J, Yellon DM, Ytrehus K, Heusch G, Ferdinandy P (2017) Novel targets and future strategies for acute cardioprotection: position Paper of the European Society of Cardiology Working Group on Cellular Biology of the Heart. Cardiovasc Res 113:564-585. https://doi.org/10.1093/cvr/cvx04 9

44. Hausenloy DJ, Kharbanda R, Rahbek Schmidt M, Moller UK, Ravkilde J, Okkels Jensen L, Engstrom T, Garcia Ruiz JM, Radovanovic N, Christensen EF, Sorensen HT, Ramlall M, Bulluck H, Evans R, Nicholas J, Knight R, Clayton T, Yellon DM, Botker HE (2015) Effect of remote ischaemic conditioning on clinical outcomes in patients presenting with an ST-segment elevation myocardial infarction undergoing primary percutaneous coronary intervention. Eur Heart J 36:1846-1848. https://doi.org/10.1093/ eurheartj/ehv249

45. Hazell AS (2007) Excitotoxic mechanisms in stroke: an update of concepts and treatment strategies. Neurochem Int 50:941-953. https://doi.org/10.1016/j.neuint.2007.04.026

46. Heusch G (2018) 25 years of remote ischemic conditioning: from laboratory curiosity to clinical outcome. Basic Res Cardiol 113:15. https://doi.org/10.1007/s00395-018-0673-2

47. Heusch G (2018) Cardioprotection research must leave its comfort zone. Eur Heart J 39:3393-3395. https://doi.org/10.1093/ eurheartj/ehy 253

48. Heusch G (2016) The coronary circulation as a target of cardioprotection. Circ Res 118:1643-1658. https://doi.org/10.1161/ CIRCRESAHA.116.308640

49. Heusch G (2017) Critical issues for the translation of cardioprotection. Circ Res 120:1477-1486. https://doi.org/10.1161/CIRCR ESAHA.117.310820

50. Heusch G, Botker HE, Przyklenk K, Redington A, Yellon D (2015) Remote ischemic conditioning. J Am Coll Cardiol 65:177-195. https://doi.org/10.1016/j.jacc.2014.10.031

51. Heusch G, Gersh BJ (2017) The pathophysiology of acute myocardial infarction and strategies of protection beyond reperfusion: a continual challenge. Eur Heart J 38:774-784. https://doi. org/10.1093/eurheartj/ehw224

52. Heusch G, Kleinbongard P, Skyschally A (2013) Myocardial infarction and coronary microvascular obstruction: an intimate, but complicated relationship. Basic Res Cardiol 108:380. https ://doi.org/10.1007/s00395-013-0380-y

53. Heusch G, Libby P, Gersh B, Yellon D, Bohm M, Lopaschuk G, Opie L (2014) Cardiovascular remodelling in coronary artery disease and heart failure. Lancet 383:1933-1943. https://doi. org/10.1016/S0140-6736(14)60107-0

54. Heusch G, Rassaf T (2016) Time to give up on cardioprotection? A critical appraisal of clinical studies on ischemic pre-, post-, and remote conditioning. Circ Res 119:676-695. https:// doi.org/10.1161/CIRCRESAHA.116.308736 
55. Heusch G, Skyschally A, Kleinbongard P (2018) Translation, translation, translation. The need for large animal studies in cardioprotection research. Circ Res 123:931-933. https://doi. org/10.1161/CIRCRESAHA.118.313947

56. Heusch G, Skyschally A, Schulz R (2011) The in situ pig heart with regional ischemia/reperfusion-ready for translation. J Mol Cell Cardiol 50:951-963. https://doi.org/10.1016/j.yjmcc .2011 .02 .016

57. Ibanez B, Heusch G, Ovize M, Van de Werf F (2015) Evolving therapies for myocardial ischemia/reperfusion injury. $\mathrm{J}$ Am Coll Cardiol 65:1454-1471. https://doi.org/10.1016/j. jacc.2015.02.032

58. Ibanez B, James S, Agewall S, Antunes MJ, Bucciarelli-Ducci C, Bueno H, Caforio ALP, Crea F, Goudevenos JA, Halvorsen S, Hindricks G, Kastrati A, Lenzen MJ, Prescott E, Roffi M, Valgimigli M, Varenhorst C, Vranckx P, Widimsky P, Group ESCSD (2018) 2017 ESC Guidelines for the management of acute myocardial infarction in patients presenting with ST-segment elevation: the task force for the management of acute myocardial infarction in patients presenting with ST-segment elevation of the European Society of Cardiology (ESC). Eur Heart J 39:119-177. https://doi.org/10.1093/eurheartj/ehx393

59. Inserte J, Cardona M, Poncelas-Nozal M, Hernando V, Vilardosa U, Aluja D, Parra VM, Sanchis D, Garcia-Dorado D (2016) Studies on the role of apoptosis after transient myocardial ischemia: genetic deletion of the executioner caspases- 3 and -7 does not limit infarct size and ventricular remodeling. Basic Res Cardiol 111:18. https://doi.org/10.1007/s00395-016-0537-6

60. Johnsen J, Pryds K, Salman R, Lofgren B, Kristiansen SB, Botker HE (2016) The remote ischemic preconditioning algorithm: effect of number of cycles, cycle duration and effector organ mass on efficacy of protection. Basic Res Cardiol 111:10. https ://doi.org/10.1007/s00395-016-0529-6

61. Jones SP, Tang XL, Guo Y, Steenbergen C, Lefer DJ, Kukreja RC, Kong M, Li Q, Bhushan S, Zhu X, Du J, Nong Y, Stowers HL, Kondo K, Hunt GN, Goodchild TT, Orr A, Chang CC, Ockaili R, Salloum FN, Bolli R (2015) The NHLBI-sponsored Consortium for preclinicAl assESsment of cARdioprotective therapies (CAESAR): a new paradigm for rigorous, accurate, and reproducible evaluation of putative infarct-sparing interventions in mice, rabbits, and pigs. Circ Res 116:572-586. https:// doi.org/10.1161/CIRCRESAHA.116.305462

62. Jung JE, Kim GS, Chen H, Maier CM, Narasimhan P, Song YS, Niizuma K, Katsu M, Okami N, Yoshioka H, Sakata H, Goeders CE, Chan PH (2010) Reperfusion and neurovascular dysfunction in stroke: from basic mechanisms to potential strategies for neuroprotection. Mol Neurobiol 41:172-179. https://doi. org/10.1007/s12035-010-8102-Z

63. Kleinbongard P, Peters J, Jakob H, Heusch G, Thielmann M (2018) Persistent survival benefit from remote ischemic preconditioning in patients undergoing coronary artery bypass surgery. J Am Coll Cardiol 71:252-254. https://doi.org/10.1016/j. jacc.2017.10.083

64. Kloner RA, King KS, Harrington MG (2018) No-reflow phenomenon in the heart and brain. Am J Physiol Heart Circ Physiol 315:H550-H562. https://doi.org/10.1152/ajpheart.00183.2018

65. Lapchak PA, Zhang JH (2018) Translational stroke research guideline projections: the 20/20 standards. Transl Stroke Res 9:9-12. https://doi.org/10.1007/s12975-017-0534-6

66. Lapchak PA, Zhang JH, Noble-Haeusslein LJ (2013) RIGOR guidelines: escalating STAIR and STEPS for effective translational research. Transl Stroke Res 4:279-285. https://doi. org/10.1007/s12975-012-0209-2

67. Lecour S, Bøtker HE, Condorelli G, Davidson SM, GarciaDorado D, Engel FB, Ferdinandy P, Heusch G, Madonna R, Ovize M, Ruiz-Meana M, Schulz R, Sluijter JP, Van Laake LW,
Yellon DM, Hausenloy DJ (2014) ESC working group cellular biology of the heart: position paper: improving the preclinical assessment of novel cardioprotective therapies. Cardiovasc Res 104:399-411. https://doi.org/10.1093/cvr/cvu225

68. Li D, Shao Z, Vanden Hoek TL, Brorson JR (2007) Reperfusion accelerates acute neuronal death induced by simulated ischemia. Exp Neurol 206:280-287. https://doi.org/10.1016/j. expneurol.2007.05.017

69. Li W, Liu J, Chen JR, Zhu YM, Gao X, Ni Y, Lin B, Li H, Qiao SG, Wang C, Zhang HL, Ao GZ (2018) Neuroprotective effects of DTIO, a novel analog of Nec-1, in acute and chronic stages after ischemic stroke. Neuroscience 390:12-29. https:// doi.org/10.1016/j.neuroscience.2018.07.044

70. Li Y, He L, Huang X, IssaBhaloo S, Zhao H, Zhang S, Pu W, Tian X, Li Y, Liu Q, Yu W, Zhang L, Liu X, Liu K, Tang J, Zhang H, Cai D, Adams RH, Xu Q, Lui KO, Zhou B (2018) Genetic lineage tracing of non-myocyte population by dual recombinases. Circulation. https://doi.org/10.1161/circulatio naha. 118.034250

71. Liu RR, Murphy TH (2009) Reversible cyclosporin A-sensitive mitochondrial depolarization occurs within minutes of stroke onset in mouse somatosensory cortex in vivo: a two-photon imaging study. J Biol Chem 284:36109-36117. https://doi. org/10.1074/jbc.M109.055301

72. Madonna R, Cadeddu C, Deidda M, Mele D, Monte I, Novo G, Pagliaro P, Pepe A, Spallarossa P, Tocchetti CG, Zito C, Mercuro $G$ (2015) Improving the preclinical models for the study of chemotherapy-induced cardiotoxicity: a position paper of the Italian Working Group on Drug Cardiotoxicity and Cardioprotection. Heart Fail Rev 20:621-631. https://doi.org/10.1007/s1074 1-015-9497-4

73. Maulik A, Davidson SM, Piotrowska I, Walker M, Yellon DM (2018) Ischaemic preconditioning protects cardiomyocytes from anthracycline-induced toxicity via the PI3 K pathway. Drugs Ther, Cardiovasc. https://doi.org/10.1007/s10557-018-6793-y

74. McGowan JV, Chung R, Maulik A, Piotrowska I, Walker JM, Yellon DM (2017) Anthracycline chemotherapy and cardiotoxicity. Cardiovasc Drugs Ther 31:63-75. https://doi.org/10.1007/ s10557-016-6711-0

75. Meybohm P, Bein B, Brosteanu O, Cremer J, Gruenewald M, Stoppe C, Coburn M, Schaelte G, Boning A, Niemann B, Roesner J, Kletzin F, Strouhal U, Reyher C, Laufenberg-Feldmann R, Ferner M, Brandes IF, Bauer M, Stehr SN, Kortgen A, Wittmann M, Baumgarten G, Meyer-Treschan T, Kienbaum P, Heringlake M, Schon J, Sander M, Treskatsch S, Smul T, Wolwender E, Schilling T, Fuernau G, Hasenclever D, Zacharowski K, Collaborators RIS (2015) A multicenter trial of remote ischemic preconditioning for heart surgery. N Engl J Med 373:1397-1407. https://doi.org/10.1056/NEJMoa1413579

76. Moustafa RR, Baron JC (2008) Pathophysiology of ischaemic stroke: insights from imaging, and implications for therapy and drug discovery. Br J Pharmacol 153(Suppl 1):S44-S54. https:// doi.org/10.1038/sj.bjp.0707530

77. Murry CE, Reinecke H, Pabon LM (2006) Regeneration gaps: observations on stem cells and cardiac repair. J Am Coll Cardiol 47:1777-1785. https://doi.org/10.1016/j.jacc.2006.02.002

78. Neuhaus AA, Couch Y, Hadley G, Buchan AM (2017) Neuroprotection in stroke: the importance of collaboration and reproducibility. Brain 140:2079-2092. https://doi.org/10.1093/brain/ awx126

79. Nighoghossian N, Berthezene Y, Mechtouff L, Derex L, Cho TH, Ritzenthaler T, Rheims S, Chauveau F, Bejot Y, Jacquin A, Giroud M, Ricolfi F, Philippeau F, Lamy C, Turc G, Bodiguel E, Domigo V, Guiraud V, Mas JL, Oppenheim C, Amarenco P, Cakmak S, Sevin-Allouet M, Guillon B, Desal H, Hosseini H, Sibon I, Mahagne MH, Ong E, Mewton N, Ovize M (2015) 
Cyclosporine in acute ischemic stroke. Neurology 84:2216-2223. https://doi.org/10.1212/WNL.0000000000001639

80. O'Collins VE, Donnan GA, Macleod MR, Howells DW (2013) Hypertension and experimental stroke therapies. J Cereb Blood Flow Metab 33:1141-1147. https://doi.org/10.1038/jcbfm .2013 .88

81. O'Collins VE, Macleod MR, Cox SF, Van Raay L, Aleksoska E, Donnan GA, Howells DW (2011) Preclinical drug evaluation for combination therapy in acute stroke using systematic review, meta-analysis, and subsequent experimental testing. J Cereb Blood Flow Metab 31:962-975. https://doi.org/10.1038/ jcbfm.2010.184

82. Pedersen F, Butrymovich V, Kelbaek H, Wachtell K, Helqvist S, Kastrup J, Holmvang L, Clemmensen P, Engstrom T, Grande P, Saunamaki K, Jorgensen E (2014) Short- and long-term cause of death in patients treated with primary PCI for STEMI. J Am Coll Cardiol 64:2101-2108. https://doi.org/10.1016/j. jacc.2014.08.037

83. Pundik S, Xu K, Sundararajan S (2012) Reperfusion brain injury: focus on cellular bioenergetics. Neurology 79:S44-S51. https:// doi.org/10.1212/WNL.0b013e3182695a14

84. Rossello X, Yellon DM (2016) Cardioprotection: the disconnect between bench and bedside. Circulation 134:574-575. https:// doi.org/10.1161/CIRCULATIONAHA.116.022829

85. Rossello X, Yellon DM (2017) The RISK pathway and beyond. Basic Res Cardiol 113:2. https://doi.org/10.1007/s0039 5-017-0662-x

86. Sandhu H, Maddock H (2014) Molecular basis of cancer-therapy-induced cardiotoxicity: introducing microRNA biomarkers for early assessment of subclinical myocardial injury. Clin Sci (Lond.) 126:377-400. https://doi.org/10.1042/CS20120620

87. Saver JL (2006) Time is brain-quantified. Stroke 37:263-266. https://doi.org/10.1161/01.STR.0000196957.55928.ab

88. Savitz SI, Baron JC, Yenari MA, Sanossian N, Fisher M (2017) Reconsidering neuroprotection in the reperfusion Era. Stroke 48:3413-3419. https://doi.org/10.1161/STROK EAHA.117.017283

89. Schinzel AC, Takeuchi O, Huang Z, Fisher JK, Zhou Z, Rubens J, Hetz C, Danial NN, Moskowitz MA, Korsmeyer SJ (2005) Cyclophilin D is a component of mitochondrial permeability transition and mediates neuronal cell death after focal cerebral ischemia. Proc Natl Acad Sci USA 102:12005-12010. https:// doi.org/10.1073/pnas.0505294102

90. Schmidt M, Jacobsen JB, Lash TL, Botker HE, Sorensen HT (2012) 25 year trends in first time hospitalisation for acute myocardial infarction, subsequent short and long term mortality, and the prognostic impact of sex and comorbidity: a Danish nationwide cohort study. BMJ 344:e356. https://doi.org/10.1136/bmj. e356

91. Sloth AD, Schmidt MR, Munk K, Kharbanda RK, Redington AN, Schmidt M, Pedersen L, Sorensen HT, Botker HE (2014) Improved long-term clinical outcomes in patients with STelevation myocardial infarction undergoing remote ischaemic conditioning as an adjunct to primary percutaneous coronary intervention. Eur Heart J 35:168-175. https://doi.org/10.1093/ eurheartj/eht369
92. Sluijter JPG, Davidson SM, Boulanger CM, Buzas EI, de Kleijn DPV, Engel FB, Giricz Z, Hausenloy DJ, Kishore R, Lecour S, Leor J, Madonna R, Perrino C, Prunier F, Sahoo S, Schiffelers RM, Schulz R, Van Laake LW, Ytrehus K, Ferdinandy P (2018) Extracellular vesicles in diagnostics and therapy of the ischaemic heart: position Paper from the Working Group on cellular biology of the heart of the European Society of Cardiology. Cardiovasc Res 114:19-34. https://doi.org/10.1093/cvr/cvx211

93. Smith CC, Davidson SM, Lim SY, Simpkin JC, Hothersall JS, Yellon DM (2007) Necrostatin: a potentially novel cardioprotective agent? Cardiovasc Drugs Ther 21:227-233. https://doi. org/10.1007/s10557-007-6035-1

94. Stone GW, Selker HP, Thiele H, Patel MR, Udelson JE, Ohman EM, Maehara A, Eitel I, Granger CB, Jenkins PL, Nichols M, Ben-Yehuda O (2016) Relationship between infarct size and outcomes following primary PCI: patient-level analysis from 10 randomized trials. J Am Coll Cardiol 67:1674-1683. https://doi. org/10.1016/j.jacc.2016.01.069

95. Szummer K, Wallentin L, Lindhagen L, Alfredsson J, Erlinge D, Held C, James S, Kellerth T, Lindahl B, Ravn-Fischer A, Rydberg E, Yndigegn T, Jernberg T (2017) Improved outcomes in patients with ST-elevation myocardial infarction during the last 20 years are related to implementation of evidence-based treatments: experiences from the SWEDEHEART registry 1995 2014. Eur Heart J 38:3056-3065. https://doi.org/10.1093/eurhe artj/ehx515

96. Thielmann M, Kottenberg E, Kleinbongard P, Wendt D, Gedik N, Pasa S, Price V, Tsagakis K, Neuhauser M, Peters J, Jakob H, Heusch G (2013) Cardioprotective and prognostic effects of remote ischaemic preconditioning in patients undergoing coronary artery bypass surgery: a single-centre randomised, double-blind, controlled trial. Lancet 382:597-604. https://doi. org/10.1016/S0140-6736(13)61450-6

97. Vermeulen Z, Segers VF, De Keulenaer GW (2016) ErbB2 signaling at the crossing between heart failure and cancer. Basic Res Cardiol 111:60. https://doi.org/10.1007/s00395-016-0576-z

98. Vicencio JM, Yellon DM, Sivaraman V, Das D, Boi-Doku C, Arjun S, Zheng Y, Riquelme JA, Kearney J, Sharma V, Multhoff G, Hall AR, Davidson SM (2015) Plasma exosomes protect the myocardium from ischemia-reperfusion injury. J Am Coll Cardiol 65:1525-1536. https://doi.org/10.1016/j.jacc.2015.02.026

99. Wang JC, Normand SL, Mauri L, Kuntz RE (2004) Coronary artery spatial distribution of acute myocardial infarction occlusions. Circulation 110:278-284. https://doi.org/10.1161/01. CIR.0000135468.67850.F4

100. Xu X, Chua KW, Chua CC, Liu CF, Hamdy RC, Chua BH (2010) Synergistic protective effects of humanin and necrostatin-1 on hypoxia and ischemia/reperfusion injury. Brain Res 1355:189194. https://doi.org/10.1016/j.brainres.2010.07.080

101. Zelniker TA, Braunwald E (2018) Cardiac and renal effects of sodium-glucose Co-transporter 2 inhibitors in diabetes: JACC state-of-the-art review. J Am Coll Cardiol 72:1845-1855. https ://doi.org/10.1016/j.jacc.2018.06.040

102. Zhang L, Zhang RL, Jiang Q, Ding G, Chopp M, Zhang ZG (2015) Focal embolic cerebral ischemia in the rat. Nat Protoc 10:539-547. https://doi.org/10.1038/nprot.2015.036 